\title{
EVALUASI TINGKAT KEPATUHAN WAJIB PAJAK UMKM DI KPP PRATAMA MAKASSAR BARAT
}

\author{
Lina Mariana \\ linamariana90@yahoo.co.id \\ Politeknik Informatika Nasional Makassar
}

\begin{abstract}
The research aims to determine the level of UMKM Taxpayer compliance based on PP No. 23 of 2018 at KPP Pratama West Makassar. The type of research used is a qualitative approach, the researcher describes the results of interviews and analyzes the data. This research conducted in June to July 2019. The level of taxpayer compliance in paying UMKM taxes from year by year has decreased significantly after having increased from 2015 to 2016, and declined again when the government applied the PP No. 23 of 2018. The KPP Pratama West Makassar devision made a program to socialize the implementation of the latest Government Regulations by distributing brochures to each of the markets and shops. The socialization is needed to notify UMKMs of the implementation of the latest Government Regulation, PP No. 23 of 2018 where the regulation confirms the reduction in UMKM tax rates to $0.5 \%$. It is doing to increase the awareness of taxpayers to follow the rules with their tax obligations.
\end{abstract}

Key words : Compliance Level, Taxpayers, UMKM

\begin{abstract}
Abstrak
Penelitian ini bertujuan untuk mengetahui tingkat kepatuhan Wajib Pajak UMKM berdasarkan PP No. 23 Tahun 2018 pada KPP Pratama Makassar Barat. Jenis penelitian yang digunakan adalah pendekatan kualitatif, yaitu peneliti menggambarkan hasil wawancara dan menganalisa data-data yang diperoleh di lapangan. Penelitian yang dilakukan pada bulan Juni sampai dengan Juli 2019. Tingkat kepatuhan Wajib Pajak dalam membayar pajak UMKM dari tahun ketahun mengalami penurunan yang signifikan setelah sempat meningkat dari tahun 2015 ke 2016, dan menurun kembali saat pemerintah menerapkan tarif PP No. 23 Tahun 2018. Pihak KPP Pratama Makassar Barat membuatkan sebuah program untuk mensosialisasikan mengenai pemberlakuan Peraturan Pemerintah terbaru dengan membagikan brosur ke tiap pasar-pasar dan kios-kios. Sosialisasi tersebut diperlukan untuk memberitahukan kepada para pelaku UMKM mengenai pemberlakuan Peraturan Pemerintah terbaru yaitu PP No/ 23 Tahun 2018 dimana dalam peraturan tersebut menegaskan tentang penurunan tarif pajak UMKM menjadi 0,5\%. Hal ini dilakukan untuk meningkatkan kesadaran Wajib Pajak untuk mematuhi kewajiban perpajakannya.
\end{abstract}

Kata Kunci: Tingkat Kepatuhan, Wajib Pajak, UMKM 


\section{PENDAhuluan}

Negara Indonesia adalah negara yang berkembang, baik dalam pembangunan maupun perekonomiannya. Kedua perkembangan tersebut akan saling berkesinambungan atau saling sambung, perekonomian yang tumbuh dengan baik tidak akan terjadi jika tidak ada pembangunan Negara yang lancar. Begitu juga pembangunan, tidak akan dapat terlaksana jika perekonomian Negara Indonesia tidak berjalan dengan baik dan sistematis. Karena permasalahan perekonomian Indonesia terletak pada sistem pemasukan Negara yang kurang begitu dimanfaatkan dengan baik.

Pada bulan Juni 2018, Pemerintah kembali meluncurkan kebijakan baru tentang perpajakan UMKM yang tertuang dalam PP No 23 Tahun 2018. Tarif pajak yang berlaku bagi UMKM dalam PP tersebut sebesar 0,5\% dan mulai berlaku per 1 Juli 2018. Kebijakan ini bertujuan untuk menstimulus bisnis UMKM, mendorong peran serta masyarakat dan pengetahuan perpajakan. (Tatik, 2018)

Pertumbuhan usaha mikro, kecil dan menengah (UMKM) di Indonesia dari tahun ke tahun semakin bertambah. Berdasarkan berita yang dilansir dari Kementerian Koperasi dan Usaha Kecil dan Menengah, pelaku UMKM kini telah mencapai $7 \%$ dari total jumlah penduduk di Indonesia. Angka ini telah meningkat tajam dari tahun 2017 yakni sebesar 3,1\%. Kenaikan jumlah pelaku UMKM yang begitu pesat tentu saja menimbulkan potensi penerimaan pajak bagi pemerintah. Transaksi - transaksi yang timbul dari UMKM ini sudah tentu menimbulkan kewajiban perpajakan bagi pelaku usahanya. Untuk memberikan kemudahan dalam melaksanakan kewajiban perpajakan, pemerintah telah merevisi aturan terkait UMKM. (Hendri, 2018)
Terkait dengan tarif pajak UMKM, Pemerintah telah beberapa kali membuat kebijakan untuk mendorong penerimaan pajak. Awalnya sudah ada ketentuan perpajakan yang mengatur tarif khusus PPh untuk UMKM tetapi hanya berlaku untuk yang berbentuk badan usaha. Dalam Undang-Undang No.36 Tahun 2008 (UU PPh) pasal 31 E dinyatakan bahwa Wajib Pajak badan dalam negeri dengan peredaran bruto sampai dengan Rp50 Miliar mendapat fasilitas berupa pengurangan tarif sebesar 50\%. Dengan tarif $\mathrm{PPh}$ Badan yang berlaku saat itu yaitu $25 \%$, maka bagi Wajib Pajak badan dalam negeri yang memenuhi syarat, tarif efektifnya menjadi $12,5 \%$ atas penghasilan sampai dengan Rp.4,8 miliar. (Tatik, 2018)

Kementerian Koperasi dan Usaha Kecil dan Menengah mencatat jumlah pelaku UMKM Indonesia mencapai hampir 60 juta pelaku usaha pada tahun 2017 yang tersebar di seluruh Indonesia. Dari 60 juta pelaku usaha, baru $\pm 2,3 \%$ (1,4 juta pelaku usaha) terdaftar pada Direktorat Jenderal Pajak dan memiliki Nomor Pokok Wajib Pajak (NPWP) pada tahun yang sama, yang terdiri dari 205.000 WP UMKM badan usaha dan 1.268.000 WP UMKM perseorangan. Dari data tersebut jelas masih banyak pelaku usaha yang belum terdaftar sebagai WP dan ini merupakan potensi pajak baru bagi pemerintah. Dibandingkan tahun sebelumnya, terdapat kenaikan jumlah WP UMKM sebesar $\pm 40 \%$ (400 ribu pelaku usaha). Adapun 1 juta pelaku UMKM tercatat pada tahun 2016. Adanya kebijakan insentif pajak UMKM menjadi peluang bagi pemerintah memunculkan lebih banyak WP (potensi pajak) UMKM baru yang akan mendorong peningkatan penerimaan pajak nonmigas. Dengan adanya kebijakan insentif pajak diharapkan WP pada akhir tahun 2018 
dapat tumbuh lebih dari 1,96 juta pelaku usaha.

Namun demikian, dilihat dari skala usaha UMKM, potensi WP baru yang dapat menjadi sasaran kebijakan ini lebih berfokus pada kelompok pelaku usaha kecil sejumlah 681.522 pelaku usaha $(1,15 \%)$ dan pelaku usaha menengah mencapai 60 ribu pelaku usaha $(0,1 \%)$. Kedua kelompok usaha ini yang "lebih siap" dalam menyetor pajak sesuai aturan yang berlaku, dibandingkan pelaku usaha mikro. Selain itu, dampak jangka pendek dari implementasi kebijakan insentif ini adalah akan terjadi penurunan penerimaan negara khususnya penerimaan pajak nonmigas pada semester kedua tahun 2018. Menurut Dirjen Pajak, total penurunan penerimaan negara diperkirakan sebesar Rp1 triliun hingga Rp1,5 triliun selama periode Juli hingga Desember 2018. Adapun penerimaan pajak dari PPh final UMKM tercatat sebesar $\pm \mathrm{Rp5}, 7$ triliun pada tahun 2017. Kontribusi pajak UMKM bersumber dari WP UMKM orang pribadi sebesar $\pm \mathrm{Rp} 3,2$ triliun dan dari WP UMKM badan sebesar \pm Rp2,5 triliun.

Di antara jenis penerimaan pajak nonmigas, kontribusi pajak dari UMKM masih rendah. Pada tahun 2017, kontribusi penerimaan PPh UMKM nya $2,2 \%$ terhadap total penerimaan, lebih rendah dibandingkan dengan penerimaan PPh usaha besar. (Sari, 2018).

\section{TINJAUAN PUSTAKA}

\section{a. Evaluasi}

Istilah evaluasi sudah menjadi kosa kata dalam bahasa Indonesia, akan tetapi kata ini adalah kata serapan dari bahasa Inggris yaitu evaluation yang berarti penilaian atau penaksiran (Echols dan Shadily, 2000 : 220). Pemahaman mengenai pengertian evaluasi dapat berbeda-beda sesuai dengan pengertian evaluasi yang bervariatif oleh para pakar evaluasi. Menurut Stufflebeam dalam Lababa, 2008 mengemukakan: "Evaluation is the process of delineating, obtaining, and providing useful information for judging decision alternatives" yang artinya evaluasi merupakan proses menggambarkan, memperoleh, dan menyajikan informasi yang berguna untuk merumuskan suatu alternatif keputusan.

Dari pengertian-pengertian tentang evaluasi yang telah dikemukakan beberapa ahli di atas, dapat ditarik benang merah tentang evaluasi yakni evaluasi merupakan sebuah proses yang dilakukan oleh seseorang untuk melihat sejauh mana keberhasilan sebuah program. Keberhasilan program itu sendiri dapat dilihat dari dampak atau hasil yang dicapai oleh program tersebut. (Retno, 2015)

\section{b. Pajak}

Membahas mengenai perpajakan tidak terlepas dari pengertian pajak itu sendiri, Prof. Dr. P. J. A. Adriani yang telah diterjemahkan oleh R., Santoso Brotodiharjo dan dikutip oleh Waluyo dalam bukunya Perpajakan Indonesia Edisi 12 - Buku 1, Penerbit Salemba Empat, Jakarta, 2017, p. 2 mengemukakan:

"Pajak adalah iuran kepada negara (yang dapat dipaksakan) yang terutang oleh yang wajib membayarnya menurut peraturan-peraturan, dengan tidak mendapat prestasi-kembali, yang langsung dapat ditunjuk, dan gunanya adalah untuk membiayai pengeluaran-pengeluaran umum berhubung dengan tugas negara yang menyelenggarakan pemerintahan."

Menurut Dr., Soeparman Soemahamidjaja dalam disertasinya yang berjudul Pajak Berdasarkan Asas Gotong Royong menyatakan: 
"Pajak merupakan iuran wajib berupa uang atau barang yang dipungut oleh pengusaha berdasarkan norma-norma hukum, guna menutupi biaya produksi barang-barang dan jasa-jasa kolektif dalam mencapai kesejahteraan umum."

Menurut Prof. Edwin R.A. Seligman dalam bukunya Essay in Taxation yang diterbitkan di Amerika menyatakan:

"Tax is compulsory contribution from the person, to the government to depray the expenses incurredin the common interest of all, without reference to special benefit conferred."

Dari definisi diatas terlihat adanya kontribusi seseorang yang ditujukan kepada negara tanpa adanya manfaat yang ditujukan secara khusus pada seseorang. Memang demikian halnya bahwa bagaimanapun juga pajak itu ditujukan manfaatnya kepada masyarakat.

Dari pengetian-pengertian tersebut, dapat disimpulkan bahwa ciri-ciri yang melekat pada pengertian pajak, adalah sebagai berikut:

1) Pajak dipungut berdasarkan undangundang serta aturan pelaksanaannya yang sifatnya dapat dipaksakan.

2) Dalam pembayaran pajak tidak dapat ditunjukkan adanya kontraprestasi individual oleh pemerintah.

3) Pajak dipungut oleh negara baik pemerintah pusat maupun pemerintah daerah.

4) Pajak diperuntukkan bagi pengeluaran-pengeluaran pemerintah, yang bila dari pemasukannya masih terdapat surplus, dipergunakan untuk membiayai public investment.

5) Pajak dapat pula mempunyai tujuan selain budgeter, yaitu mengatur.

Dari definisi yang telah dijelaskan pada poin sebelumnya, maka dapat disimpulkan bahwa unsur-unsur yang terdapat pada definisi tersebut adalah:

1) Iuran dari rakyat kepada negara yang berhak memungut pajak adalah negara.

2) Berdasarkan Undang-undang, pajak dipungut berdasarkan atau dengan kekuatan Undang-undang serta aturan pelaksanaannya

3) Digunakan untuk membiayai rumah tangga Negara, yakni pengeluaranpengeluaran yang bermanfaat bagi masyarakat luas

Sebagaimana telah diketahui ciriciri yang melekat pada pengertian pajak dari berbagai definisi, terlihat adanya dua fungsi pajak, yaitu sebagai berikut:

1) Fungsi Penerimaan (Budgeter)

Pajak berfungsi sebagai sumber dana yang diperuntukkan bagi pembiayaan pengeluaran pemerintah. Sebagai contoh: dimasukkannya pajak dalam APBN sebagai penerimaan dalam negeri.

2) Fungsi Mengatur (Reguler)

Pajak berfungsi sebagai alat untuk mengatur atau melaksanakan kebijakan dibidang sosial dan ekonomi. Sebagai contoh: dikenakannya pajak lebih tinggi terhadap minuman keras, dapat ditekan. Demikian pula terhadap barang mewah.

Untuk mencapai tujuan pemungutan pajak perlu memegang teguh asas-asas pemungutan dalam memilih alternatif pemungutannya, sehingga terdapat keserasian pemungutan pajak dengan tujuan dan asas yang masih diperlukan lagi yaitu pemahaman atas perlakuan pajak tertentu. Asas-asas pemungutan pajak sebagaimana dikemukakan oleh Adam Smith dalam buku An Inquiri into the Nature and Cause of the Wealth of Nations menyatakan 
bahwa pemungutan pajak hendaknya didasarkan pada asas-asas berikut.

1) Equality

Pemungutan pajak harus bersifat adil dan merata, yaitu pajak dikenakan kepada orang pribadi yang harus sebanding dengan kemampuan membayar pajak (ability to pay) dan sesuai dengan manfaat yang diterima. Adil dimaksudkan bahwa setiap wajib pajak menyumbangkan uang untuk pengeluaran pemerintah sebanding dengan kepentingannya dan manfaat yang diminta.

2) Certainty

Penetapan pajak itu tidak ditentukan sewenang-wenang pihak otoritas pajak. Oleh karena itu, wajib pajak harus mengetahui secara jelas dan pasti besarnya pajak yang terutang, kapan harus dibayar, serta batas waktu pembayaran.

3) Convenience

Kapan wajib pajak itu harus membayar pajak sebaiknya sesuai dengan saatsaat yang tidak menyulitkan wajib pajak. Sebagai contoh: pada saat wajib pajak memperoleh penghasilan. Sistem pemungutan ini disebut pay as you earn.

4) Economy

Secara ekonomi bahwa biaya pemungutan dan biaya pemenuhan kewajiban wajib pajak diharapkan seminimum mungkin, demikian pula beban yang ditanggung wajib pajak.

Asas keadilan dalam prinsip perundang-undangan perpajakan maupun dalam hal pelaksanaannya harus dipegang teguh walaupun keadilan itu sangat relatif. Menurut Richard A. Musgrave dan Peggy B. Musgrave dalam buku Public Finance in Theory and Practice terdapat dua macam asas keadilan pemungutan pajak, adalah sebagai berikut.
1) Benefit Principle

Dalam sistem perpajakan yang adil, setiap wajib pajak harus membayar pajak sejalan dengan manfaat yang dinikmatinya dari pemerintah. Pendekatan ini disebut revenue and expenditure approach.

2) Ability Principle

Dalam pendekatan ini menyarankan agar pajak dibebankan kepada wajib pajak atas dasar kemampuan membayar.

Masalah keadilan dalam pemungutan pajak, dibedakan antaralain sebagai berikut:

1) Keadilan Horizontal

Pemungotan pajak adil secara horizontall apabila beban pajaknya sama atas semua waib pajak yang memperoleh penghasilan sama denganjumlah tanggungan yang sama, tanpa membedakan jenis penghasilan atau sumber penghasilan.

2) Keadian Vertikal

Keadilan dapat dirumuskan (horizontal dan vertikal) bahwa pemungutan pajak adil, apabilaorang dalam kondisiekonomis yang sama dikenakan pajak yang sama, demikian sebaliknya.

Seperti yang dikemukakan Mansury, Pajak Penghasilan (sebagai contoh dalam uraian ini) hendaknya dipungut sesuai dengan asas keadilan, maka diperlukan syarat keadilan sebagai berikut.

1) Syarat keadilan horizontal, antara lain sebagai berikut:

a) Definisi Penghasilan Memuat semua tambahan kemampuan ekonomis termasuk kedalam pengertian definisi penghasilan.

b) Globality 
Seluruh tambahan kemampuan ekonomis merupakan ukuran dari keseluruhan kemampuan membayar (the global ability to pay). Oleh karena itu, penghasilan dijumlahkan menjadi satu sebagai objek pajak.

c) Net Income

Ability to pay yaitu jumlah neto setelah dikurangi semua biaya yang tergolong dalam biaya untuk mendapatkan, menagih, dan memelihara penghasilan.

d) Personal Exemption

Pengurangan yang diberikan kepada wajib pajak orang pribadi berupa Penghasilan Tidak Kena Pajak (PTKP).

e) Equal Treatment for the Equals

Pengenaan pajak dengan perlakuan yang sama dapat diartikan bahwa seluruh penghasilan dikenakan pajak dengan tarif yang sama tanpa membedakan jenis atau sumber penghasilan.

2) Syarat keadilan vertikal, antara lain sebagai berikut.

a) Unequal Treatment for the Unequals

Besarnya tarif dibedakan oleh jumlah seluruh penghasilan atau jumlah seluruh penghasilan atau jumlah seluruh tambahan kemampuan ekonomis (bukan perbedaan jenis atua sumber penghasilan).

b) Progression

Wajib pajak yang penghasilannya besar, harus membayar pajak yang besar dengan presentase tarif yang besar.

Asas pemungutan lainnya juga dikemukakan oleh John F. Due dalam buku Government Finance, An Economic Analisys yaitu the neutrality principle yang bermakna bahwa pajak itu harus netral artinya tidak mempengaruhi pilihan masyarakat untuk mengonsumsi atau memproduksi barang. Terlihat bahwa asas ini bertujuan untuk menjaga agar pemungutan pajak tidak mengganggu kemajuan ekonomi. Namun, dimungkinkan kebijaksanaan pemerintah justru dibuat untuk mempengaruhi konsumsi masyarakat. Asas pemungutan pajak dapat pula dibagi dalam beberapa asas, adalah sebagai berikut.

\section{1) Asas Menurut Falsafah Hukum}

Hukum pajak harus mendasarkan keadilan. Selanjutnya keadilan ini sebagai asas pemungutan pajak. Untuk menyatakan keadilan kepada hak negara untuk memungut pajak, muncul beberapa teori dasar, sebagai berikut.

a) Teori Asuransi

Dalam perjanjian asuransi diperlukan pembayaran premi. Premi tersebut dimaksudkan sebagai pembayaran atas usaha melindungi orang dari segala kepentingannya, misalnya keselamatan atau keamanan harta bendanya. Teori asuransi ini menyamakan pembayaran premi dengan pembayaran pajak. Walaupun kenyataannya menyatakan bahwa dengan premi tersebut tidaklah tepat.

b) Teori Kepentingan

Pada teori kepentingan ini memperhatikan beban pajak yang harus dipungut dari masyarakat. Pembebanan ini harus didasarkan pada kepentingan setiap orang pada tugas pemerintah termasuk perlindungan jiwa dan hartanya. Oleh karena itu, pengeluaran negara untuk melindunginya dibebankan pada masyarakat.

c) Teori Gaya Pikul

Teori ini mengandung maksud bahwa dasar keadilan pemungutan pajak terletak pada jasa-jasa yang diberikan oleh negara kepada masyarakat berupa perlindungan jiwa dan harta bendanya. Oleh karena itu, untuk kepentingan perlindungan, maka 
masyarakat akan membayar pajak menurut gaya pikul seseorang.

d) Teori Bakti

Teori bakti ini disebut juga teori kewajiban pajak mutlak. Teori ini berdasarkan pada negara mempunyai hak mutlak untuk memungut pajak. Di lain pihak, masyarakat menyadari bahwa pembayaran pajak sebagai suatu kewajiban untuk membuktikan tanda baktinya terhadap negara. Dengan demikian dasar hukum pajak terletak pada hubungan masyarakat dengan negara.

e) Teori Asas Daya Beli

Dalam teori ini berdasaran bahwa peneylenggaraan kepentingan masyarakat yang dianggap sebagai dasar keadilan pemungutan pajak yang bukan kepentingan individu atau negara, sehingga lebih menitikberatkan pada fungsi pengatur.

2) Asas Yuridis

Untuk menyatakan suatu keadilan, hukum pajak harus memberikan jaminan hukum kepada negara atau warganya. Oleh karena itu, pemungutan pajak harus didasarkan pada undang-undang. Landasan hukum pemungutan pajak di Indonesia adalah pasal 23A Amandemen Undang-Undang Dasar 1945.

3) Asas Ekonomi

Seperti pada uraian sebelumnya, pajak mempunyai fungsi regular dan fungsi budgeter. Asas ekonomi ini lebih menekankan pada pemikiran bahwa negara menghendaki agar kehidupan ekonomi masyarakat agar terus meningkat. Untuk itu, pemungutan pajak harus diupayakan tidak menghambat kelancaran ekonomi sehingga kehidupan ekonomi tidak terganggu.
4) Asas Pemungutan Pajak Lainnya

Terdapat tiga asas yang digunakan untuk memungut pajak dalam Pajak Penghasilan adalah sebagai berikut.

a) Asas Tempat Tinggal

Negara-negara mempunyai hak untuk memungut atas seluruh penghasilan Wajib Pajak berdasarkan tempat tinggal Wajib Pajak. Wajib Pajak yang bertempat tinggal di Indonesia dikenai pajak atas penghasilan yang diterima atau diperoleh, yang berasal dari Indonesia atau berasal dari luar negeri (Pasal 4 Undang-Undang Pajak Penghasilan)

b) Asas Kebangsaan

Pengenaan pajak dihubungkan dengan suatu negara. Asas ini diberlakukan kepada setiap orang asing yang bertempat tinggal di Indonesia untuk membayar pajak.

c) Asas Sumber

Negara mempunyai hak untuk memungut pajak atas penghasilan yang bersumber pada suatu negara yang memungut pajak. Dengan demikian, Wajib Pajak menerima atau memperoleh penghasilan dari Indonesia dikenakan pajak di Indonesia tanpa memperhatikan tempat tinggal Wajib Pajak. (Waluyo, 2017)

Pajak dapat dikelompokkan menjadi tiga kelompok, yaitu:

1) Menurut golongan atau pembebanan, dibagi menjadi berikut ini:

a) Pajak langsung, adalah pajak yang bebannya tidak dapat dilimpahkan pihak lain, tetapi harus menjadi beban langsung Wajib Pajak yang bersangkutan. Contoh: Pajak Penghasilan.

b) Pajak tidak langsung, adalah pajak yang pembebanannya dapat dilimpahkan kepada pihak lain. Contoh: Pajak Pertambahan Nilai. 
2) Menurut Sifat

Pembagian pajak menurut sifat dimaksudkan pembedaan dan pembagian berdasarkan ciri-ciri prinsip adalah sebagai berikut:

a) Pajak subjektif, adalah pajak yang yang pemungutannya/ pengenaannya berpangkal atau berdasarkan pada subjeknya yang selanjutnya dicari syarat objektifnya, dalam arti memperhatikan keadaan dari Wajib Pajak. Contoh: Pajak Penghasilan

b) Pajak objektif, adalah pajak yang berpangkal atau berdasarkan dengan objeknya, tanpa memperhatikan keadaan diri Wajib Pajak. Contoh: Pajak Peryambahan Nilai dan Pajak Penjualan atas Barang Mewah

3) Menurut pemungut dan pengelolanya, adalah sebagai berikut:

a) Pajak pusat, adalah pajak yang dipungut oleh pemerintah pusat dan digunakan untuk membiayai rumah tangga negara. Contoh: Pajak Penghasilan, Pajak Pertambahan Nilai, dan Pajak Penjualan atas Barang Mewah, Pajak Bumi dan Bangunan, dan Bea Materai.

b) Pajak daerah, adalah pajak yang dipungut oleh pemerintah daerah dan digunakan untuk membiayai rumah tangga daerah. Contoh: pajak reklame, pajak hiburan, Bea Perolehan Hak atas Tanah dan Bangunan (BPHTB), Pajak Bumi dan Bangunan sektor perkotaan dan pedesaan (PBB P2)

\section{c. Kepatuhan Wajib Pajak}

Machfud sidik yang dikutip oleh Siti

Kurnia Rahayu dalam bukunya Perpajakan Indonesia: Konsep dan Aspek Formal, Graha Ilmu, 2010, p. 137-138 mengemukakan bahwa:

"Kepatuhan memenuhi kewajiban perpajakan secara sukarela merupakan tulang punggung Self Assestment System, dimana wajib pajak bertanggungjawab menetapkan sendiri kewajiban perpajakan dan kemudian secara akurat dan tepat waktu membayar dan melaporkan pajaknya tersebut".

Pengertian kepatuhan pajak (tax compliance) adalah bahwa wajib pajak mempunyai kesediaan untuk mematuhi kewajiban pajaknya sesuai aturan yang berlaku tanpa perlu diadakannya pemeriksaan, investigasi seksama (obtrusive investigation), peringatan ataupun ancaman dan penerapan sanksi baik hukum maupun administrasi. Loebbecke (2003) mengemukakan kepatuhan wajib pajak sebagai suatu tingkatan dimana seorang wajib pajak memenuhi peraturan perpajakan di negaranya. Pendapat lain tentang kepatuhan wajib pajak juga dikemukakan oleh Kiryanto (2000), seperti dikutip oleh Jatmiko (2006) yang menyatakan suatu iklim kepatuhan wajib pajak adalah:

1) Wajib pajak paham dan berusaha memahami UU Perpajakan

2) Mengisi formulir pajak dengan benar

3) Menghitung pajak dengan jumlah yang benar.

4) Membayar pajak tepat pada waktunya Internal Revenue Service

$$
\text { Sedangkan (Brown dan }
$$
Maznur,2003) megelompokkan kepatuhan wajib pajak terdiri dari 3 tipe kepatuhan:

1) Kepatuhan penyerahan SPT (filling compliance)

2) Kepatuhan pembayaran (Payment compliance)

3) Kepatuhan pelaporan (reporting compliance)

Utami (2008) menegaskan bahwa kepatuhan wajib pajak mutlak diberlakukan guna mencapai suatu efektivitas tingkat penerimaan pajak yang baik terutama bagi Negara Republik 
Indonesia. Kepatuhan juga dapat diartikan sebagai intensitas wajib pajak untuk mengisi dan melaporkan SPT serta menyetorkan pajak yang terutang berdasarkan undang-undang dan peraturan yang berlaku. (Marcori, 2018).

Sesuai dengan PMK Nomor 192/PMK.03/2007 Pasal 1, wajib pajak yang dapat ditetapkan sebagai wajibpajak patuh yang dapat diberikan pengembalian pendahuluan kelebihan pembayaran pajak apabila memenuhi semua syarat sebagai berikut:

1) Tepat waktu dalam menyampaikan Surat Pemberitahuan.

2) Tidak mempunyai tunggakan pajak untuk semua jenis pajak, kecuali tunggakan pajak yang telahmemperoleh izin mengangsur atau menunda pembayaran pajak.

3) Laporan keuangan diaudit oleh akuntan publik atau lembaga pengawas keuangan pemerintahdengan pendapat wajar tanpa pengecualian selama 3 tahun berturut-turut

4) Tidak pernah dipidana karena melakukan tindak pidana dibidang perpajakan berdasar putusanpengadilan yang telah mempunyai kekuatan hukum tetap dalam jangka waktu 5 tahun terakhir. (Tatik, 2018)

\section{d. Usaha Mikro, Kecil dan Menengah (UMKM)}

Sesuai dengan Undang- Undang Nomor 20 Tahun 2008 tentang Usaha Mikro, Kecil dan Menengah (UMKM), pengertian Usaha Mikro, Kecil dan Menengah adalah sebagai berikut:

1) Usaha Mikro adalah usaha produktif milik orang perorangan dan/atau badan usaha peroranganyang memenuhi kriteria Usaha Mikro sebagaimana diatur dalam UndangUndang.
2) Usaha Kecil adalah usaha ekonomi produktif yang berdiri sendiri, yang dilakukan oleh orangperorangan atau badan usaha yang bukan merupakan anak perusahaan atau bukan cabangperusahaan yang dimiliki, dikuasai, atau menjadi bagian baik langsung maupun tidak langsungdari usaha menengah atau usaha besar yang memenuhi kriteria Usaha Kecil sebagaimana dimaksud dalam UndangUndang.

3) Usaha Menengah adalah usaha ekonomi produktif yang berdiri sendiri, yang dilakukan oleh orangperseorangan atau badan usaha yang bukan merupakan anak perusahaan atau cabang perusahaanyang dimiliki, dikuasai, atau menjadi bagian baik langsung maupun tidak langsung dengan UsahaKecil atau usaha besar dengan jumlah kekayaan bersih atau hasil penjualan tahunan sebagaimanadiatur dalam Undang-Undang. Adapun kriteria usaha mikro, kecil dan menengah adalah sebagai berikut:

\begin{tabular}{|c|c|c|c|}
\hline \multirow{2}{*}{ No } & \multirow{2}{*}{ Uraian } & \multicolumn{2}{|l|}{ Kriteria } \\
\hline & & Asset & Omzet \\
\hline 1 & Usaha Mikro & Maks. 50 Juta & Maks. 300 Juta \\
\hline 2 & Usaha Kecil & > 50 Juta - 500 Juta & > 300 Juta - 2,5 Miliyar \\
\hline 3 & $\begin{array}{l}\text { Usaha } \\
\text { Menengah }\end{array}$ & $>500$ Juta - 10 Miliyar & $>2,5$ Miliyar - 50 Miliyar \\
\hline
\end{tabular}

Tabel 1 Kriteria UMKM

Tabel diatas menjelaskan kriteria UMKM berdasarkan asset dan omzet per tahun, bahwa Usaha Mikro adalah usaha yang memiliki asset maksimal Rp50.000.000 dan omzet maksimal Rp300.000.000. Usaha Kecil memiliki asset lebih dari Rp50.000.000 sampai dengan Rp500.000.000 dan omzet lebih dari Rp300.000.000 sampai dengan Rp2.500.000.000. Sedangkan Usaha Menengah memiliki asset lebih dari Rp500.000.000 sampai dengan Rp10.000.000.000 dan omzet lebih dari 
Rp2.500.000.000 sampai dengan Rp 50.000.000.000. (Tatik, 2018)

\section{e. Kerangka Pikir/Konseptual}

Suatu negara pada hakikatnya memiliki tujuan yaitu mensejahterakan rakyatnya. Salah satu cara yang dilakukan oleh pemerintah dalam upaya mencapai tujuan tersebut ialah dengan dilakukannya pembiayaan pembangunan dengan memperoleh sumber utama pembiayaan yang berasal dari pajak. Penurunan tarif sebesar $0,5 \%$ yang dicurahkan pada PP No. 23 Tahun 2018 diharapkan mampu menggiring wajib pajak yang merupakan pelaku UMKM untuk menaati kewajiban perpajakannya. Karena pajak merupakan penerimaan terbesar untuk negara dan merupakan salah satu sumber yang diutamakan maka pihak pemerintah khususnya Dirjen Pajak memberikan keleluasaan bagi wajib pajak untuk melaksanakan kewajiban perpajakannya dengan pengharapan tingkat kepatuhan wajib pajak meningkat dari tahun ke tahun.

Berdasarkan penjelasan diatas, maka alur penelitan ini akan mengkaji mengenai Tingkat Kepatuhan Wajib Pajak berdasarkan PP No. 23 Tahun 2018.

\begin{tabular}{l}
$\begin{array}{l}\text { Kantor Pelayanan Pajak } \\
\text { Pratama Makassar Barat }\end{array}$ \\
\begin{tabular}{|l|}
\hline Peraturan Perpajakan No. 23 Tahun 2018 \\
(PP No. 23 Thn. 2018)
\end{tabular} \\
\hline $\begin{array}{l}\text { Tingkat Kepatuhan Wajib Pajak } \\
\text { (Pelaku UMKM) }\end{array}$ \\
\hline
\end{tabular}

Gambar 1 Kerangka Pikir/Konseptual

\section{METODE PENELITIAN}

a. Teknik Analisis Data

Analisis data diartikan sebagai upaya data yang sudah tersedia kemudian diolah dengan statistik dan dapat digunakan untuk menjawab rumusan masalah dalam penelitian. Dengan demikian, teknik analisis data dapat diartikan cara melaksanakan analisis terhadap data, dengan tujuan mengolah data tersebut untuk menjawab rumusan masalah.

Adapun teknik analisis data yang digunakan oleh peneliti, adalah:

1. Teknik Analisis Kualitatif

Adalah metode yang lebih menekankan pada aspek pemahaman secara mendalam terhadap suatu masalah daripada melihat permasalahan untuk penelitian generalisasi. Metode penelitian ini lebih suka menggunakan teknik analisis mendalam (in-depth analysis), yaitu mengkaji masalah secara kasus perkasus karena metodologi kulitatif yakin bahwa sifat suatu masalah satu akan berbeda dengan sifat dari masalah lainnya. Tujuan dari metodologi ini bukan suatu generalisasi tetapi pemahaman secara mendalam terhadap suatu masalah. Penelitian kualitatif berfungsi memberikan kategori substantif dan hipotesis penelitian kualitatif.

2. Teknik Analisis Deskriptif

Teknik analisis data deskriptif merupakan tekhnik analisis yang dipakai untuk menganalisis data dengan mendeskripsikan atau menggambarkan data-data yang sudah dikumpulkan seadanya tanpa ada maksud membuat generalisasi dari hasil penelitian. Yang termasuk dalam teknik analisis data statistik deskriptif diantaranya seperti penyajian data kedalam bentuk grafik, tabel, presentase, frekuensi, diagram, grafik, mean, modus, dan lain-lain. 


\section{HASIL DAN PEMBAHASAN}

\section{a. Hasil Penelitian}

Salah satu metode yang digunakan untuk menggali data dalam penelitian ini adalah dengan melakukan observasi langsung disertai dengan wawancara. Metode ini digunakan untuk mengevaluasi kepatuhan Wajib Pajak berdasarkan Peraturan Perpajakan Nomor 23 Tahun 2018 di KPP Pratama Makassar Barat

Adapun data yang diperoleh peneliti mengenai jumlah Wajib Pajak yang terdaftar dan patuh dalam kewajiban perpajakannya di KPP Pratama Makassar Barat.

\begin{tabular}{||l||l||l||}
\hline No & Tahun & WP Badan Terdaftar \\
\hline \hline 1 & 2015 & 10.468 \\
\hline \hline 2 & 2016 & 10.930 \\
\hline \hline 3 & 2017 & 11.489 \\
\hline \hline 4 & 2018 & 11.910 \\
\hline \hline 5 & 2019 & 12.354 \\
\hline
\end{tabular}

Tabel 2 Wajib Pajak Terdaftar pada KPP Pratama Makassar Barat

\begin{tabular}{||l||l||l||l||}
\hline No & Tahun & $\begin{array}{c}\text { WP Badan } \\
\text { Terdaftar Wajib } \\
\text { SPT }\end{array}$ & SPT Terealisasi \\
\hline \hline 1 & 2015 & 3.958 & 2.305 \\
\hline \hline 2 & 2016 & 3.762 & 2.316 \\
\hline \hline 3 & 2017 & 3.522 & 2.130 \\
\hline \hline 4 & 2018 & 4.319 & 2.355 \\
\hline \hline 5 & 2019 & 4.256 & 2.098 \\
\hline
\end{tabular}

Tabel 3 Wajib Pajak Terdaftar Wajib SPT dan SPT yang terealisasi di KPP Pratama Makassar Barat

TINGKAT KEPATUHAN WAJIB PAJAK DI KPP PRATAMA MAKASSAR BARAT

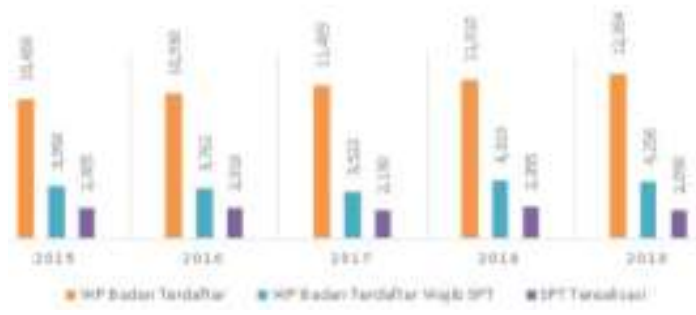

Diagram 1 Tingkat Kepatuhan Wajib Pajak Pratama Makassar Barat

\section{b. Pembahasan}

Saat pertama kali Peraturan Pemerintah No. 23 Tahun 2018 diterapkan, pihak KPP Pratama Makassar Barat tak henti-hentinya melakukan sosialisasi mengenai tarif pajak yang telah turun menjadi $0,5 \%$ kepada para pelaku UMKM. Meskipun begitu, tetap saja masih ada beberapa wajib pajak yang kurang memahami atau lalai untuk melaporkan kewajiban perpajakannya sehingga data SPT terealisasi yang terekam di KPP Pratama Makassar Barat mengalami peningkatan dan penurunan secara bergantian tiap tahunnya sejak 2015 hingga 2019.

Selanjutnya, Kepala Seksi Pengolahan Data dan Informasi di KPP Pratama Makassar Barat menyatakan:

"Dari segi kendala sistem tidak ada yang berubah, hanya perubahan tarif saja. Namun, kita selalu mensosialisasikan dan menyampaikan setiap saat kepada Wajib Pajak jika sekarang tarif pajak UMKM yang tadinya $1 \%$ turun menjadi $0,5 \%$."

\section{1) Wajib Pajak Badan yang Terdaftar di KPP Pratama Makassar Barat}

Dari data yang disajikan pada tabel

3, dapat disimpulkan bahwa Wajib Pajak Badan terdaftar dari tahun ke tahun mengalami peningkatan terhitung sejak 2015 hingga 2019. Dimana pada tahun 2015 sebanyak 10.468 Wajib Pajak, tahun 2016 sebanyak 10.930 Wajib Pajak, tahun 2017 sebanyak 11.489 Wajib Pajak, tahun 2018 sebanyak 11.910, dan pada tahun 2019 sebanyak 12.354 Wajib Pajak.

Peningkatan jumlah Wajib Pajak terdaftar yang meningkat dari tahun ke tahun tersebut menjadi gambaran mengenai tingginya tingkat kesadaran masyarakat, terkhusus para pelaku UMKM untuk memenuhi kewajiban perpajakan mereka yang nantinya akan menambah pendapatan Negara sebagai 
pembiayaan dan pengeluaran oleh pemerintah dalam membangun fasilitas yang nantinya akan digunakan oleh masyarakat.

\section{2) Wajib Pajak Badan Wajib SPT dan SPT Terealisasi}

Berdasarkan tabel 5, jelas tertera bahwa setiap tahunnya jumlah wajib pajak yang patuh terhitung sejak 2015 sampai dengan 2019 mengalami peningkatan dan penurunan secara bergantian, mengingat kembali bahwa Peraturan Pemerintah No.23 Tahun 2018 mulai diterapkan pada Juni 2018 tersebut menjadi puncak meningkatnya wajib pajak patuh diantara tahun-tahun data yang disajikan dan menurun secara signifikan di tahun 2019.

Pada tahun 2015 jumlah Wajib Pajak UMKM yang melaporkan SPTnya sebanyak 2.305 Wajib Pajak. Sementara dari jumlah UMKM yang terdaftar wajib SPT sebanyak 3.958 Wajib Pajak.

Pada tahun 2016 jumlah Wajib Pajak UMKM yang melaporkan SPTnya mengalami peningkatan yaitu sebanyak 2.316 Wajib Pajak. Sementara dari jumlah UMKM yang terdaftar wajib SPT sebanyak 3.762 Wajib Pajak yang dimana mengalami penurunan dari tahun sebelumnya. Pada tahun 2017 jumlah Wajib Pajak UMKM yang melaporkan SPTnya kembali menurun menjadi 2.130 Wajib Pajak. Sementara dari jumlah UMKM yang terdaftar wajib SPT sebanyak 3.522 Wajib Pajak, yang dimana mengalami penurunan dari tahun sebelumnya.

Pada tahun 2018 jumlah Wajib Pajak UMKM yang melaporkan SPTnya meningkat jauh dari tahun-tahun sebelumnya sebanyak 2.355 Wajib Pajak. Sementara dari jumlah UMKM yang terdaftar wajib SPT sebanyak 4.319, yang juga mengalami peningkatan yang sangat signifikan dari tahun-tahun sebelumnya.
Kemudian pada tahun 2019 jumlah Wajib Pajak UMKM yang melaporkan SPTnya kembali menurun melampaui tahuntahun sebelumnya sebanyak 2.098 Wajib Pajak. Sementara dari jumlah UMKM yang terdaftar wajib SPT sebanyak 4.257 Wajib Pajak, dimana mengalami penurunan dari tahun sebelumnya.

\section{3) Tingkat Kepatuhan Wajib Pajak UMKM}

\begin{tabular}{||l||l||l|l||l||}
\hline No. & $\begin{array}{l}\text { Tahun } \\
\text { Pajak }\end{array}$ & $\begin{array}{l}\text { WP Badan } \\
\text { Terdaftar Wajib } \\
\text { SPT }\end{array}$ & $\begin{array}{l}\text { SPT yang } \\
\text { Terealisasi }\end{array}$ & $\begin{array}{l}\text { Persentase } \\
\text { Tingkat } \\
\text { Kepatuhan }\end{array}$ \\
\hline \hline 1 & 2015 & 3.958 & 2.305 & $58 \%$ \\
\hline 2 & 2016 & 3.762 & 2.316 & $61 \%$ \\
\hline \hline 3 & 2017 & 3.522 & 2.130 & $60 \%$ \\
\hline \hline 4 & 2018 & 4.319 & 2.355 & $54 \%$ \\
\hline 5 & 2019 & 4.256 & 2.098 & $49 \%$ \\
\hline
\end{tabular}

Tabel 2 Tingkat Kepatuhan Wajin Pajak UMKM di KPP Pratama Makassar Barat

Dari table 6 dijelaskan bahwa tahun 2015 jumlah Wajib Pajak yang terdaftar di KPP Pratama Makassar Barat sebanyak 10.468 Wajib Pajak dengan jumlah Wajib Pajak UMKM yang melaporkan SPTnya sebanyak 2.305 Wajib Pajak dengan persentase tingkat kepatuhan sebesar $58 \%$.

Pada tahun 2016 jumlah Wajib Pajak yang terdaftar sebanyak 10.930 Wajib Pajak dengan jumlah Wajib Pajak UMKM yang melaporkan SPTnya sebanyak 2.316 Wajib Pajak dengan persentase tingkat kepatuhan sebesar $61 \%$.

Pada tahun 2017 jumlah Wajib Pajak yang terdaftar sebanyak 11.489 Wajib Pajak dengan jumlah Wajib Pajak UMKM yang melaporkan SPTnya sebanyak 2.130 Wajib Pajak dan persentase tingkat kepatuhan sebesar $60 \%$.

Pada tahun 2018, saat pertama kali diberlakukannya PP No. 23 Tahun 2018 jumlah Wajib Pajak yang terdaftar sebanyak 11.910 Wajib Pajak dengan jumlah Wajib Pajak UMKM yang melaporkan SPTnya sebanyak 2.355 
Wajib Pajak dengan persentase tingkat kepatuhan sebesar 54\%. Sedangkan tahun 2019, jumlah Wajib Pajak yang terdaftar sebanyak 12.354 Wajib Pajak dengan jumlah Wajib Pajak UMKM yang melaporkan SPTnya sebanyak 2.098 Wajib Pajak dan persentase tingkat kepatuhan sebesar 49\%.

Berdasarkan data yang disajikan, hasil penelitian menunjukkan bahwa tingkat kepatuhan Wajib Pajak UMKM setiap tahunnya semakin menurun setelah pernah mengalami peningkatan dari tahun 2015 ke 2016 hingga kembali menurun ditahun-tahun selanjutnya.

PERSENTASE TINGKAT KEPATUHAN WAJIB PAJAK DI KPP PRATAMA MAKASSAR BARAT

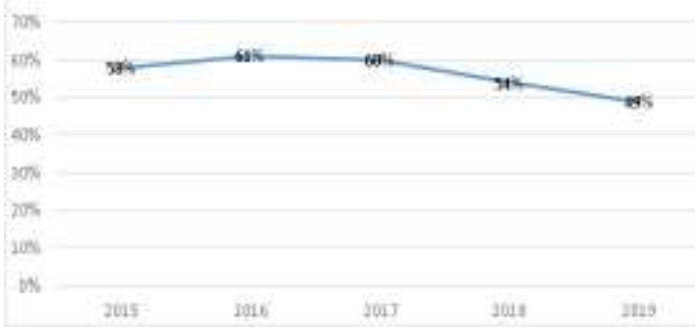

Diagram 2 Persentase Tingkat Kepatuhan Wajib Pajak Berdasarkan PP No. 23 Tahun 2018 di KPP Pratama Makassar Barat

\section{4) Upaya dalam Peningkatan Kepatuhan Wajib Pajak}

Adapun upaya yang dilakukan oleh KPP Pratama Makassar Barat dalam meningkatkan kepatuhan Wajib Pajak dalam memenuhi kewajiban perpajakannya, yaitu:

a. Sosialisasi

Sejak diberlakukannya PP No. 23 Tahun 2018, pihak KPP Makassar Barat gencar melakukan sosialisasi kepada para pelaku UMKM mengenai turunnya tarif pajak UMKM menjadi 0,5\%. Selanjutnya, Bapak Danan Widayat menyatakan bahwa:

"Kami mempunyai program sosialisasi dengan cara menyebarkan brosur untuk pelaku UMKM disekitaran pasarpasar atau kios-kios kecil, dan juga mejelaskan bahwa ada Peraturan Pemerintah baru sebagai pengganti dari PP No. 46 Tahun 2008 yaitu PP No. 23 Tahun 2018, dimana persennya yang tadinya $1 \%$ diubah menjadi $0,5 \%$. Selain itu juga kami juga mensosialisasikan mengenai PP baru ini ditiap acara-acara yang mengundang kami."

Perkembangan teknologi juga dimanfaatkan oleh pihak KPP Pratama Makassar Barat dalam mensosialisasikan PP No. 23 Tahun 2018 ini, baik di sosial media maupun website resmi milik DJP.

\section{PENUTUP}

\section{a. Simpulan}

Berdasarkan hasil penelitian dan pembahasan yang diuraikan pada bab sebelumnya, maka peneliti menarik kesimpulan bahwa:

1. Tingkat kepatuhan Wajib Pajak dalam membayar pajak UMKM dari tahun ketahun mengalami penurunan yang signifikan setelah sempat meningkat dari tahun 2015 ke 2016, dan menurun kembali saat pemerintah menerapkan tarif PP No. 23 Tahun 2018. Tingkat kepatuhan Wajib Pajak UMKM dalam membayar pajak secara tepat waktu pada tahun 2015 sebesar $58 \%$, kemudian sempat mengalami kenaikan pada tahun 2016 sebesar $61 \%$ dan kembali menurun lagi ditahun selanjutnya yaitu 2017 menjadi 60\%. Sama seperti tahun sebelumnya, di tahun 2018 pada saat diterapkannya PP No. 23 Tahun 2018, tingkat kepatuhan Wajib Pajak menurun menjadi $54 \%$ dan selanjutnya ditahun 2019 tingkat kepatuhan Wajib Pajak menurun menjadi 49\%.

2. Pihak KPP Pratama Makassar Barat membuatkan sebuah program untuk mensosialisasikan 
pemberlakuan Peraturan Pemerintah terbaru dengan membagikan brosur ke tiap pasar-pasar dan kios-kios. Sosialisasi tersebut diperlukan untuk memberitahukan kepada para pelaku UMKM mengenai pemberlakuan Peraturan Pemerintah terbaru yaitu PP No/ 23 Tahun 2018 dimana dalam peraturan tersebut menegaskan tentang penurunan tarif pajak UMKM menjadi $0,5 \%$. Hal ini dilakukan untuk meningkatkan kesadaran Wajib Pajak untuk mematuhi kewajiban perpajakannya.

\section{b. Saran}

Adapun saran yang dapat peneliti berikan untuk dapat mengoptimalkan tingkat kepatuhan wajib pajak antara lain:

1. Untuk lebih meningkatkan tingkat kepatuhan Wajib Pajak UMKM maka KPP Pratama Makassar Barat harus lebih gencar mensosialisasikan mengenai Peraturan Pemerintah terbaru, baik mensosialisasikannya secara langsung kepada Wajib Pajak UMKMnya atau menyebarkannya melalui media sosial yang memungkinkan mudah untuk dijangkau oleh para pelaku UMKM. Dan juga menjelaskan kepada Wajib Pajak mengenai keuntungan apa saja yang bisa mereka peroleh dari mematuhi kewajiban perpajakannya.

2. KPP Pratama Makassar Barat sebaiknya lebih mengingatkan kembali kepada Wajib Pajak mengenai sanksi yang akan dikenakan apabila Wajib Pajak tidak mematuhi/lalai dalam kewajiban perpajakannya.

\section{DAFTAR PUSTAKA}

Waluyo. (2017). Perpajakan Indonesia. Jakarta: Salemba Empat.

Waluyo. (2017). Perpajakan Indonesia Edisi 12. 2.

Sujarweni, V. W. (2018). Metodologi Penelitian. Yogyakarta: Pustaka Baru Press.

Ananti, R. (2018). Artikel Pajak. Direktorat Penyuluhan, P. D. (2013). Undang-Undang Kup Dan Peraturan Pelaksanaannya. Jakarta: Direktorat Jenderal Pajak.

Haeruddin. (2017). Akmen. Jurnal Ilmiah, 286.

Hendri. (2018). Implementasi Sosialisasi Peraturan Pemerintah No. 23 Tahun 2018 Bagi Pelaku Usaha Mikro, Kecil dan Menengah (UMKM). Jurnal Vokasi Indonesia, 54.

Jobapri. (2013, Maret 07). Buku Panduan Hak dan Kewajiban Wajib Pajak.

Marcori, F. (2018). Pengaruh Kesadaran Wajib Pajak, Pelayanan Fiskus, Dan Sanksi Pajak Terhadap Kepatuhan Wajib Pajak Orang Pribadi Yang Melakukan Usaha Kecil Menengah. 2.

Mulyo Agung, S. d. (2016). Perpajakan Indonesia. Jakarta: Lembaga Pendidikan dan Pengembangan Profesi Indonesia.

Pratiwi, A. (2017, Oktober 25). Peraturan Menteri Keuangan Republik Indonesia Nomor 79/PMK.01/2015 .

Retno, I. (2015). Evaluasi Program Nasional Pemberdayaan Masyarakat Mandiri Pedesaan. Digital Repository Unila.

Sari, R. (2018). Kebijakan Intensif Pajak bagi Usaha Mikro, Kecil, dan Menengah. Info Singkat, 21-22. 
Sari, R. (2018). Kebijakan Intensif Pajak bagi Usaha Mikro, Kecil, dan Menengah. Info Singkat, 22.

Suparman, R. A. (2008, Januari 26). Catatan Perpajakan.

Tatik. (2018). Potensi Kepatuhan Pembayaran Pajak Pada Pelaku UMKM (Usahamikro Kecil Dan Menengah) Pasca Penerbitan Peraturan Pemerintah Nomor 23 Tahun 2018. Seminar Nasional dan Call for Paper Sustainable Competitive Advantage (SCA) 8, 1.

Tatik. (2018). Potensi Kepatuhan Pembayaran Pajak Pada Pelaku UMKM (Usahamikro Kecil Dan Menengah) Pasca Penerbitan Peraturanpemerintah Nomor 23 Tahun 2018. SCA, 2.

Peraturan Pemerintah Republik Indonesia Nomor 23 Tahun 2018 Tentang Pajak Penghasilan Atas Penghasilan Dari Usaha Yang Diterima Atau Diperoleh Wajib Pajak Yang Memiliki Peredaran Bruto Tertentu 